\title{
Aplikasi Penambahan Kunyit Dan Multinutrien Blok Plus Pada Ransum Kambing Jawarandu Terhadap Infestasi Endoparasit Dan Konsumsi Pakan
}

\section{Application of the Addition of Turmeric and Multinutrient Block Plus into the Jawarandu Goat's Diet on Endoparasite Infestations and Feed Consumption}

\section{Retno Iswarin Pujaningsih ${ }^{1) *}$, Dian Wahyu Harjanti ${ }^{2}$, Baginda Iskandar Moeda Tampubolon ${ }^{2)}$, Widianto ${ }^{2)}$, Ahmad Ahsan ${ }^{2)}$ dan Wening Suri Pawestri ${ }^{2)}$}

1) Sekolah Vokasi Universitas Diponegoro, Semarang

${ }^{2)}$ Fakultas Peternakan dan Pertanian Universitas Diponegoro, Semarang

Article history

Received: Jul 30, 2020

Accepted: Feb 10, 2021

* Corresponding author:

E-mail:

retnoiswarinpujaning@lectur

er.undip.ac.id

DOI:

10.46549/jipvet.v11i1.128

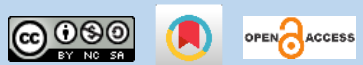

\begin{abstract}
Goat management in rural areas is still commonly done traditionally with little regard for health factors. One factor is the presence of parasitic worms in the goat's digestive tract which disturbs growth. This research aimed to evaluate the effect of the addition of turmeric and multi-nutrient block plus (MNBP) on eliminating endoparasites and increasing feed intake of Jawarandu goats. The material used was 12 male Jawarandu goats weighing an average of $20 \mathrm{~kg}$ each. A completely randomized design was used in this study with 4 treatments and 3 replications. Treatment T0: basal ration + MNBP; T1: T0 + 1\% turmeric; T2: T0 $+3 \%$ turmeric; $\mathrm{T} 3: \mathrm{T} 0+5 \%$ turmeric. The parameters observed were feed intake, weight gain, number of endoparasites, and total eggs per gram of feces. Data analysis was done with the analysis of variance with a significance level of 5\% to determine the effect of treatment. If there is a treatment effect, it is followed through by Duncan's multiple range test. The results showed a decrease in the number of endoparasites. The best treatment to induce the antibody system into action was T2 treatment, namely the addition of turmeric with a level of $3 \%$. Feed intake was not significantly increased although there was an increase of body weight gain in T2 and T3. The study concludes that the administration of MNBP and turmeric with a level of $5 \%$ has not been able to eliminate all endoparasites until the 28th day. MNBP and turmeric are useful as natural antioxidants. Increased levels of turmeric can increase weight gain and improve the goats' immune system.
\end{abstract}

Keyword: Multinutrient blocks; Turmeric; Jawarandu goats; Endoparasite; Feed intake.

Abstrak
Pengelolaan kambing di pedesaan masih lazim dilakukan secara tradisional
angan kurang mengindahkan faktor-faktor kesehatan. Salah satu faktor adalah
tumbuhan parasit pada saluran pencernaan kambing yang menyebabkan
nambahan kunyit dan multinutrien blok plus (MNBP) dalam mengeliminasi
doparasit dan meningkatkan konsumsi pakan kambing Jawarandu. Materi
ng digunakan adalah 12 ekor kambing Jawarandu jantan bobot rata-rata $20 \mathrm{~kg}$.
ncangan acak lengkap digunakan pada penelitian ini dengan 4 perlakuan dan
+ 3\% kungan. Perlakuan T0 : Ransum basal + MNBP ; T1 : T0 + $1 \%$ kunyit ; T2 :
kan, pertambahan berat badan, jumlah endoparasit dan total telur tiap gram
es. Analisis data menggunakan analisis varians taraf signifikasi $5 \%$ untuk
ngetahui adanya pengaruh perlakuan. Apabila terdapat pengaruh perlakuan,


maka dilanjutkan dengan uji jarak berganda Duncan. Hasil penelitian menunjukkan adanya penurunan jumlah endoparasit. Perlakuan terbaik untuk menginduksi sistem antibodi adalah perlakuan T2 yakni dengan penambahan kunyit dengan aras 3\%. Konsumsi pakan tidak berbeda nyata antar perlakuan tetapi pertambahan berat badan meningkat pada kambing perlakuan T2 dan T3. Simpulan penelitian bahwa pemberian MNBP dan kunyit dengan aras 5\% belum mampu menghilangkan semua endoparasit sampai hari ke-28. MNBP dan kunyit bermanfaat sebagai antioksidan alami. Peningkatan aras kunyit dapat meningkatkan, pertambahan berat badan dan sistem imunitas ternak uji.

Kata kunci: Multinutrien blok; Kunyit; Kambing jawarandu; Endoparasite; Konsumsi pakan.

\section{PENDAHULUAN}

Kesehatan hewan menjadi salah satu hal yang penting. Berbagai penyakit sangat rentan terhadap ternak. Salah satunya penyakit cacing. Ternak kambing yang dipelihara peternak sering terserang penyakit cacingan sehingga dalam pakan ternak perlu ditambahkan anthelmintic (Widiarso dan Wida, 2019). Anthelmintic berfungsi untuk pencegahan dan pengendalian bagi ternak yang menderita cacingan (Ekawasti et al., 2019). Harga obat cacing relative mahal dan tidak terjangkau bagi petani peternak di pedesaan, disamping itu ketersediaannya terbatas di lapangan. Untuk mensiasati keadaan tersebut dapat diberikan obat-obatan tradisional antara lain daun pepaya. Keberadaan zat aktif di dalam daun papaya berupa papain, flavonoid, saponin, tannin, karpain dan alkaloid diketahui memiliki sifat toksik bagi cacing. Cara kerja zat aktif tersebut adalah dengan menekan kerja sistem saraf dan mengkoagulasikan albumin (Oktofani dan Suwandi, 2019). Penggunaan obat tradisional secara umum dinilai lebih aman dari pada penggunaan obat modern. Hal ini disebabkan karena obat tradisional memiliki efek samping yang relatif lebih sedikit dari pada obat modern (Sari, 2006). WHO juga mendukung upaya-upaya dalam peningkatan keamanan dan khasiat dari obat tradisional (WHO, 2003).

Daun papaya yang diolah menjadi tepung diberikan sebagai pakan pelengkap berupa multinutrien blok. Multinutrien blok merupakan feed supplement yang mengandung energi, protein dan mineral untuk ternak ruminansia dalam bentuk blok maupun silinder padat (Singh et al. 2015). Penggunaan MNB sebagai feed supplement bermanfaat dalam melengkapi kebutuhan nutrisi pada ternak sehingga dapat meningkatkan produktivitasnya. Feed supplement tersebut mampu mengoptimalkan kinerja mikroba rumen karena pakan yang dikonsumsi oleh ternak menjadi mudah untuk didegradasi (Suharyono et al. 2014). Firsoni dan Ansori (2015) menyimpulkan bahwa suplementasi urea molases multinutrien blok dengan glirisida dapat meningkatkan produksi gas, degradabilitas dan produksi biomassa mikroba ruminansia. Pemberian MNB untuk tenak ruminansia kecil seperti kambing dan domba berkisar antara $70-150 \mathrm{~g} /$ hari (Wulandari, 2019). MNB merupakan pakan pelengkap yang dapat diberikan bersamaan dengan konsentrat sebelum ternak diberikan pakan hijauan/berserat (Fardana et al., 2019).

Multinutrien blok dapat dibuat dari bahanbahan seperti misalnya fermentasi jerami padi, tepung cangkang kerang, garam, urea, bentonit dan molasses. Kelebihan lain MNB diantaranya yaitu dapat diterapkan pada wilayah dengan keterbatasan pasokan pakan utama dan memiliki kualitas pakan yang rendah (Fardana et al., 2019). Hasil penelitian Pujaningsih et al. (2018) mendapatkan bahwa analisis MNB secara kimiawi menunjukkan adanya peningkatan protein dan kualitas mikrobiologi secara kuantitatif. Sehingga dapat disimpulkan bahwa herbal multinutrisi blok dapat diberikan kepada ternak sebagai pakan pelengkap Teknologi pengolahan pakan MNBP tergolong mudah untuk dibuat dan diikuti oleh peternak skala kecil serta bahan-bahan penyusunnya murah dan mudah untuk didapatkan.

Palatabilitas pada kambing juga perlu diperhatikan supaya makanan yang diberikan 
dapat dikonsumsi sepenuhnya oleh kambing. Pada penelitian ini untuk menambah palatabilitas ditambahkan kunyit pada multinutrien blok tersebut. Kunyit merupakan salah satu jenis akar - akaran yang mengandung minyak atsiri dan kurkumin (Hayakawa et. al., 2011). Kandungan zat aktif dalam kunyit juga memiliki sifat sebagai antiinflamasi dan antioksidan (Kusbiantoro dan Purwaningrum, 2018). Zat aktif yang dominan pada kunyit merupakan kurkumin yang dapat membangkitkan nafsu makan dan berperan sebagai imunomodulator untuk meningkatkan sistem imunitas yaitu dengan respon imun non spesifik dan imun spesifik melalui peningkatan fungsi dari sel limfosit (Pangestika et al., 2012).

Penelitian ini bertujuan untuk mengkaji pengaruh MNBP dan kunyit dalam mengeliminasi endoparasite, profil hematologi dan konsumsi pakan pada kambing Jawarandu.
Diduga pemberian MNBP dan kunyit dapat mengeliminasi endoparasit pada kambing Jawarandu serta dapat meningkatkan sistem imunitas pada ternak sehingga mampu meningkatkan konsumsi pakannya.

\section{METODE PENELITIAN}

Materi yang digunakan dalam penelitian adalah 12 ekor kambing Jawarandu jantan dengan bobot rata-rata $19,53 \mathrm{~kg} \pm 1,39 \mathrm{~kg}$. Ternak uji ditempatkan masing-masing pada kendang individual. Pakan basal diberikan berupa hijauan dan konsentrat dengan rasio 80 : 20. Konsentrat diformulasikan seperti pada Tabel 1 dan MNBP disusun seperti pada Tabel 2. Hijauan yang diberikan adalah rumput odot dan fermentasi pongkol singkong. Fermentasi pongkol singkong dan fermentasi jerami padi dibuat menggunakan EM4 sebagai starter.

\section{Tabel 1. Formulasi Konsentrat}

\begin{tabular}{clc}
\hline No. & \multicolumn{1}{c}{ Bahan Pakan } & Komposisi $(\%)$ \\
\hline 1. & Dedak padi & 20 \\
\hline 2. & Pollard & 35 \\
\hline 3. & Onggok & 11 \\
4. & DDGS & 17 \\
\hline 5. & Bungkil kelapa & 10 \\
6. & Kulit kopi & 3 \\
\hline. & Tetes & 4 \\
\hline
\end{tabular}

Tabel 2. Komposisi Multinutrien Blok dengan 2\% daun pepaya

\begin{tabular}{clc}
\hline \hline No. & \multicolumn{1}{c}{ Bahan Pakan } & Komposisi (\%) \\
\hline 1. & Jerami padi fermentasi & 34 \\
2. & Daun papaya & 2 \\
3. & Molases & 40 \\
4. & Tepung cangkang kerang darah & 10 \\
5. & Garam & 3 \\
6. & Urea & 4 \\
7. & Bentonit & 7 \\
\hline
\end{tabular}

Pakan diberikan selama 2,5 bulan observasi setelah diadaptasikan 1 bulan. MNBP diberikan satu kali sehari sebelum pemberian konsentrat pada pagi hari. Diikuti dengan pemberian hijauan pakan 1 jam sesudahnya. Air minum disediakan secara ad libitum.

Rancangan acak lengkap digunakan dengan 3 perlakuan dan 4 ulangan. Perlakuan yang diberikan adalah penambahan tepung kunyit dengan level 0\%, 1\%, 3\%, dan 5\% dari berat kering pakan konsentrat yang diberikan serta pemberian MNBP sebanyak 100 gram/ekor/hari. Parameter yang diamati meliputi konsumsi pakan, pertambahan berat badan, jenis endoparasit dan total telur tiap gram feses.

Penimbangan bobot badan ternak dilaksanakan setiap 2 minggu sekali. 
Pengambilan data telur cacing tiap gram feses dilakukan secara berkala setiap satu minggu sekali dalam jangka waktu satu bulan. Sampel feses kemudian dibawa ke Laboratorium Kesehatan Hewan Semarang untuk diidentifikasi jenis endoparasit dan total telur tiap gram feses dengan metode withlock (Nurtjahyani dan Agustin, 2014). Total telur tiap gram feses nematoda dan trematoda dihitung menggunakan rumus sebagai berikut.

$$
\begin{aligned}
& \text { Nematoda }=\frac{(\text { Vol. feses }+ \text { gula jenuh }) / \text { Vol. ruang } \text { Whitlock }}{\text { Berat feses }} \ldots . . \\
& \text { Trematoda }=\frac{(\text { Vol. sedimen }+ \text { gula jenuh }) / \text { Vol. ruang } \text { Whitlock }}{\text { Berat feses }}
\end{aligned}
$$

Data Telur Tiap Gram Tinja (TTGT) dianalisis dengan metode deskriptif. Data konsumsi pakan dan pertambahan berat badan dianalisis dengan ANOVA.

\section{HASIL DAN PEMBAHASAN}

\section{Jenis Endoparasit dan Total Telur Tiap Gram} Tinja (TTGT)

Hasil analisis telur tiap gram tinja menunjukkan bahwa semua ternak uji positif terinfeksi endoparasit sebelum diberi perlakuan. Hasil analisis sampel feses ternak uji menemukan adanya jenis-jenis endoparasit yang ditemukan dari kelas Nematoda meliputi Strongyloides sp., Haemonchus sp., Nematodirus sp., Charbetia sp., Trichostrongylus sp., Oeshophagustumum sp., Monieza sp., Cooperia sp., Trichuris sp., Bunostumum sp., dan Ostertagia sp. serta dari kelas Trematoda yaitu Fasciola sp.
Strongyloides sp merupakan endoparasit yang paling dominan menginfeksi kambing Jawarandu selama periode penelitian. Hal ini berkaitan dengan kemampuan berkembangbiak cacing Strongyloides yang cepat. Menurut Mulyadi (2018) perkembangan telur Strongyloides menjadi larva invektif membutuhkan waktu sekitar 24 jam sehingga menyebabkan perkembangbiakan cacing ini menjadi sangat pesat. Ternak uji yang terinfeksi endoparasit digolongkan dalam infeksi ringan yang dapat dilihat dari nilai total telur tiap gram feses (berkisar antara $5-470$ butir). Menurut Rozi et al. (2015) tingkat infeksi diklasifikasikan dalam infeksi ringan jika jumlah telur yang ditemukan tiap gram feses adalah 1 - 499 butir. Jumlah endoparasit dari berbagai spesies dijumlahkan dan ditampilkan pada Tabel 3. untuk melihat perubahan dari jumlah telur cacing dalam feses.

\begin{tabular}{|c|c|c|c|c|c|}
\hline \multirow{2}{*}{ Perlakuan } & Hari ke-0 & Hari ke-7 & Hari ke-14 & Hari ke-21 & Hari ke-28 \\
\hline & \multicolumn{5}{|c|}{---------------------------------- telur per gram---------------------------------- } \\
\hline $\mathrm{T}_{0}$ & 60 & 290 & 245 & 435 & 65 \\
\hline $\mathrm{T}_{1}$ & 470 & 45 & 190 & 100 & 20 \\
\hline $\mathrm{T}_{2}$ & 5 & 0 & 130 & 35 & 20 \\
\hline $\mathrm{T}_{3}$ & 10 & 140 & 10 & 15 & 15 \\
\hline
\end{tabular}

Tabel 3. Perubahan Total Telur Cacing tiap Gram Feses Selama Penelitian (deskriptif)

Keterangan : $\mathrm{T}_{0}$ :Pakan basal $+\mathrm{MNBP} ; \mathrm{T}_{1}:$ Pakan basal $+\mathrm{MNBP}+1 \%$ kunyit; $\mathrm{T}_{2}:$ Pakan basal + MNBP + 3\% kunyit; $\mathrm{T}_{3}:$ Pakan basal $+\mathrm{MNBP}+5 \%$ kunyit

Periode nol menunjukkan bahwa semua ternak positif terinfeksi oleh cacing kelas Nematoda (Tabel 3). Ternak yang diberi perlakuan $\mathrm{T}_{0}$ mengalami peningkatan jumlah telur cacing pada periode pertama $(79,38 \%)$. Jumlah telur meningkat karena pada periode ini terdapat cacing yang memasuki umur 21 hari sehingga pada periode ini cacing menghasilkan telur. Menurut McAnulty and Cook (2019) cacing betina dewasa akan mulai menghasilkan telur pada hari ke-21 setelah menginfeksi ternak. Jumlah telur pada periode kedua menurun $(20,62 \%)$ karena siklus cacing pada periode ini terdiri dari (a) cacing yang sudah berumur 21 hari berkurang jumlahnya; (b) cacing muda yang berumur $\leq 10$ hari dan; (c) cacing muda yang berumur $\geq 10$ hari. Jumlah telur pada periode ketiga meningkat $(25,24 \%)$ karena siklus cacing pada periode ini terdiri dari (a) cacing yang sudah berumur 21 hari jumlahnya lebih banyak (b) cacing muda yang berumur $\leq 10$ hari (c) cacing muda yang 
berumur $\geq 10$. Jumlah telur pada periode ke empat menurun $(88,35 \%)$ karena siklus cacing pada periode ini terdiri dari (a) cacing yang sudah berumur 21 hari berkurang jumlahnya dari 3 periode sebelumnya (b) cacing muda yang belum berumur $\leq 10$ hari sudah memasuki tahap untuk bertelur (c) cacing muda yang berumur $\geq 10$. Jadi, pemberian multinutrien blok plus $2 \%$ tepung daun pepaya tidak berpengaruh secara signifikan terhadap penurunan jumlah telur. Cacing pada tubuh kambing dapat dibunuh melalui dua cara yaitu dengan bahan aktif yang terdapat pada MNBP dan tepung kunyit. Berdasarkan Tabel 4 diketahui bahwa baik pada MNBP dan kunyit keduanya mengandung zat aktif flavonoid yaitu pada MNBP sebesar 1,91\%(b/b) sedangkan pada kunyit yaitu sebesar 4,00\% (b/b) yang berperan untuk membunuh cacing.

Tabel 4. Kandungan Zat Aktif Multinutrien Blok Plus (MNBP) dan Kunyit

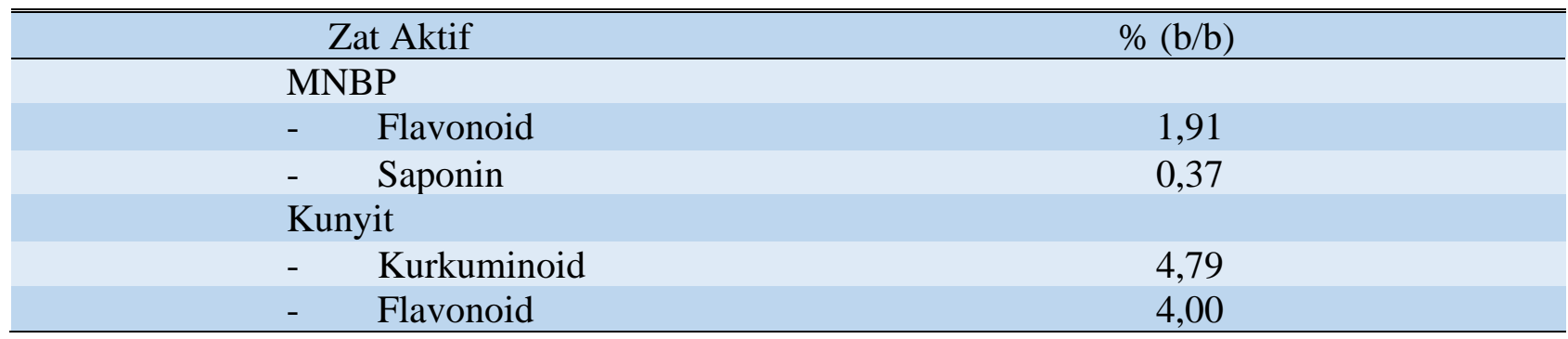

Flavonoid merupakan kelompok fenol yang mudah diserap dan apabila berkontak dengan cacing akan menyebabkan denaturasi protein dalam jaringan cacing. Kemampuan anthelmintik pada flavonoid menyebabkan denaturasi protein pada jaringan cacing katika flavonoid diserap oleh tubuh cacing. Cacing dapat dibunuh dengan peningkatan antibodi yang dibentuk tubuh dalam jangka waktu 14 hari. Keberadaan cacing dalam tubuh merangsang pembentukan IgE. IgE akan berikatan dengan permukaan tubuh cacing yang diikat eosinofil kemudian granul pada eosinofil akan mengeluarkan enzim untuk menghancurkan cacing (Fisdiora et al.,2018). Penurunan jumlah telur cacing pada hari ke 21 (Tabel 3) mengindikasikan bahwa jumlah cacing yang menghasilkan telur telah berkurang. Perubahan bertambah dan berkurangnya jumlah telur selama pengamatan juga disebabkan oleh siklus kehidupan cacing di tubuh cacing yang umurnya heterogeny. Umur cacing untuk bertelur adalah 21 hari

Pengaruh pemberian tepung kunyit dengan aras $1 \%$ dan $3 \%$ mempunyai pola perubahan yang sama yaitu pada periode pertama turun kemudian meningkat pada periode kedua, lalu polanya menurun pada periode ketiga dan ke empat. Faktor yang menyebabkan perubahan pada pola peningkatan dan penurunan jumlah telur adalah siklus hidup cacing serta efektivitas MNBP dan kunyit. Pada periode nol, sudah terdapat cacing yang umurnya heterogen dengan kriteria (a) cacing berumur 21 hari yang memasuki masa produksi telur (b) cacing muda yang berumur $\leq 10$ hari (c) cacing muda yang berumur $\geq 10$ hari (kelompok $b$ dan $\mathrm{c}$ belum memproduksi telur). Penurunan telur cacing pada periode pertama ( $\mathrm{T}_{1}$ sebesar $96,35 \%$ dan $\mathrm{T}_{3}$ sebesar $100 \%$ ) disebabkan karena adanya bahan aktif baik pada daun pepaya dan kunyit yang bersifat racun bagi cacing sehingga dapat mengganggu metabolisme pada cacing dan berdampak pada kematian. Peningkatan telur cacing pada periode kedua ( $\mathrm{T}_{1}$ sebesar $93,51 \%$ dan $\mathrm{T}_{3}$ sebesar $100 \%$ ) disebabkan karena pada periode ini siklus cacing terdiri dari: (a) cacing berumur 21 hari yang memasuki masa produksi jumlahnya lebih banyak (b) cacing muda yang berumur $\leq 10$ hari bertambah (c) cacing muda yang berumur $\geq 10$ hari bertambah. Pemberian MNBP dan kunyit dalam periode ini tidak efektif dalam membunuh cacing. Kandungan bahan aktif flavonoid pada MNBP dan kunyit serta kurkumin dalam membentuk antibodi pada periode ini belum mampu membunuh semua cacing yang ada di tubuh kambing. Penurunan telur cacing pada periode ketiga $\left(\mathrm{T}_{1}\right.$ sebesar $76,62 \%$ dan $\mathrm{T}_{3}$ sebesar $95,56 \%$ ) disebabkan karena pada periode ini cacing yang 
berumur 21 hari, cacing muda baik yang berumur $\leq 10$ hari dan $\geq 10$ hari berkurang. Penurunan telur cacing pada periode ketiga dan keempat $\left(\mathrm{T}_{1}\right.$ sebesar 96,35 dan $58,15 \%$ serta $\mathrm{T}_{3}$ sebesar $100 \%$ dan $60 \%$ ) disebabkan karena cacing pada tubuh kambing dapat dibunuh sehingga tidak menghasilkan telur lagi. Dampak adanya bahan aktif baik pada daun pepaya dan kunyit yang bersifat racun bagi cacing sehingga dapat mengganggu metabolisme yang berdampak kematian pada cacing.

Pengaruh pemberian kunyit dengan aras $5 \%$ mempunyai pola sebagai berikut. Pola pada periode pertama mengalami peningkatan kemudian pada periode kedua turun lalu pada periode ketiga meningkat dan tetap pada periode keempat. Peningkatan telur cacing $(83,36 \%)$ disebabkan karena pada periode ini, siklus cacing terdiri dari: (a) cacing berumur 21 hari yang memasuki masa produksi jumlahnya lebih banyak (b) cacing muda yang berumur $\leq 10$ hari (c) cacing muda yang berumur $\geq 10$ hari. Pemberian MNBP dan kunyit dalam periode ini tidak efektif dalam membunuh cacing. Kandungan bahan aktif flavonoid pada MNBP dan kunyit serta kurkumin dalam membentuk antibodi pada periode ini belum mampu membunuh semua cacing yang ada di tubuh kambing. Penurunan telur cacing pada periode kedua $(100 \%)$ disebabkan karena adanya bahan aktif flavonoid baik pada daun pepaya dan kunyit yang bersifat racun bagi cacing sehingga dapat mengganggu metabolisme pada cacing dan berdampak pada kematian. Kurkumin yang terkandung pada kunyit mulai terbentuk pada periode ini sehingga jumlah cacing yang mati semakin tinggi. Jumlah telur cacing tetap pada periode keempat. Jumlah telur cacing yang tetap dibanding periode sebelumnya disebabkan karena pada periode keempat terdapat cacing yang kebal, sehingga pemberian kunyit sampai dengan aras 5\% tidak mampu membunuh cacing.

Masih ditemukannya endoparasit sampai dengan hari ke-28 diduga karena konsentrasi daun pepaya dalam MNBP yang digunakan tergolong kecil yaitu 2\%. Namun demikian, konsentrasi daun pepaya yang hanya $2 \%$ pada
MNBP mampu mengurangi endoparasit. Diduga, endoparasit dapat dieliminasi, jika konsentrasi pepaya yang digunakan ditingkatkan. Berdasarkan penelitian yang telah dilakukan oleh Zingare et al. (2018) penggunaan ekstrak biji pepaya dengan dosis $100 \mathrm{mg} / \mathrm{kg}$ bobot badan kambing mampu mengeliminasi cacing di saluran pencernaan pada hari ke-21 secara efektif sebesar 90,47\% .

Konsumsi bahan kering (BK) dan pertambahan berat badan (PBB)

Hasil penelitian menunjukkan bahwa konsumsi pakan tidak berbeda nyata antar perlakuan $(\mathrm{P}>0,05)$. Penambahan level tepung kunyit $1 \%, 3 \%$ dan 5\% pada ransum tidak menunjukkan adanya peningkatan nafsu makan pada masing-masing perlakuan dikarenakan ternak makan untuk memenuhi kebutuhannya dan akan berhenti makan jika telah terpenuhi kebutuhannya. Meskipun demikian, jika dibandingkan dengan standar dari Kearl (1982) maka konsumsi BK untuk hidup pokok kambing dengan berat 20 sampai $25 \mathrm{~kg}$ (540640 gram) telah terpenuhi bahkan lebih (764,92-846,63 gram).

Peningkatan konsumsi pakan dengan tambahan pelengkap MNBP dan tepung kunyit ini seiring dengan peningkatan konsumsi bahan aktif sehingga antioksidan di dalam tubuh meningkat. Menurut Andarina dan Djauhari (2017) jika radikal bebas dan antioksidan tidak berikatan, maka reaksi oksidasi akan terus berlanjut dan membentuk reaksi berantai yang berdampak pada stres oksidatif. Salah satu dampak dari stres oksidatif adalah kerusakan pada sel-sel imun. Menurut Primawati (2014) kunyit memiliki kandungan senyawa aktif yaitu kurkumin yang dapat digunakan sebagai imunomodulator. Prasetiadi et al., (2017) menyatakan bahwa kandungan kurkuminoid, minyak atsiri, vitamin dan mineral pada kunyit berfungsi untuk meningkatkan kekebalan tubuh (imunitas) dan menambah nafsu makan. Konsumsi pakan menurut Qurniawan (2016) adalah salah satu faktor yang mempengaruhi bobot badan selain jenis kelamin, lingkungan, bibit dan kualitas pakan. 
Tabel 5. Rerata Konsumsi Bahan Kering dan Pertambahan Berat Badan Kambing Jawarandu yang Diberi Pakan Pelengkap MNBP dan Kunyit Selama 3 Bulan

\begin{tabular}{lcccc}
\hline \multicolumn{1}{c}{ Rerata } & T0 & T1 & T2 & T3 \\
\hline $\begin{array}{l}\text { Konsumsi pakan } \\
\text { (g/ekor/hari) }\end{array}$ & 1104.94 & 1063,07 & 1059,36 & 1061,1 \\
$\begin{array}{l}\text { Pertambahan berat } \\
\text { Badan (g/ekor/hari) }\end{array}$ & $126,33^{\mathrm{a}}$ & $150,52^{\mathrm{b}}$ & $168,00^{\mathrm{bc}}$ & $171,56^{\mathrm{c}}$ \\
\hline
\end{tabular}

Keterangan: $\mathrm{T} 0=$ pakan basal $+\mathrm{MNB} 2 \%$ daun papaya + kunyit $0 \%, \mathrm{~T} 1=\mathrm{T} 0+$ kunyit $1 \%, \mathrm{~T} 2=\mathrm{T} 0+$ kunyit $3 \%, \mathrm{~T} 3=$ $\mathrm{T} 0+$ kunyit $5 \%$.

Pemberian MNBP dan tepung kunyit pada penelitian ini terbukti positif mampu meningkatkan imunitas tubuh. Sehingga meskipun di dalam saluran pencernaannya terdapat endoparasite, adanya anthelmintic herbal pada MNBP yang mengandung daun papaya dan tambahan kunyit terbukti mampu mengurangi infestasi cacing yang dapat mengganggu konsumsi pakannya dan pertambahan berat badan tetap dapat dicapai dengan baik.

\section{KESIMPULAN DAN SARAN}

Pemberian MNBP dan tepung kunyit belum mampu menghilangkan semua endoparasit sampai hari ke-28. MNBP dan tepung kunyit bermanfaat sebagai antioksidan alami. Peningkatan aras kunyit dapat meningkatkan pertambahan berat badan dan sistem imunitas ternak uji.

\section{UCAPAN TERIMA KASIH}

Ucapan terimakasih disampaikan kepada Direktorat Riset dan Pengabdian Masyarakat Direktorat Jenderal Penguatan Riset dan Pengembangan Kementrian Riset, Teknologi, dan Pendidikan Tinggi yang telah memberikan dana untuk menyelesaikan penelitian ini. Penghargaan yang tinggi untuk tim MNB , bapak Sri Julianto beserta tenaga kandang yang telah membantu pelaksanaan penelitian hingga selesai.

\section{Daftar Pustaka}

Andarina R dan T Djauhari. 2017. Antioksidan dalam dermatologi. J. Kedokteran dan Kesehatan. 4 (1): 39-48.

Ekawasti F, Suhardono DA, Dewi E, Martindah AH, Wardhana dan DH Sawitri. 2019. Skrining Efektivitas Ekstrak Tanaman
Herbal sebagai Anthelmintik terhadap Telur dan Larva Nematoda serta Cacing Haemonchus contortus secara In Vitro. Prosiding. Seminar Nasional Teknologi Peternakan dan Veteriner 2019. DOI: http://dx.doi.org/10.14334/Pros.Semnas.T PV-2019-p.462-473

Fardana DH, BIM Tampoebolon, E Pangestu, Widiyanto dan RI Pujaningsih. 2019. Evaluasi pemberian pakan dengan jumlah multinutrien blok yang berbeda sebagai suplemen terhadap performans kambing kacang. J. Litbang Provinsi Jawa Tengah. 1 (17): 88-99

Firsoni dan D Ansori. 2015. Manfaat Urea Molasses Multinutrient Blok (UMMB) yang Mengandung Tepung Daun Glirisidia (Gliricidia sepium) secara In-vitro. Jurnal Ilmiah Aplikasi Isotop dan Radiasi 11(02): 161-170.

Fisdiora Z, U Balqis dan M Hambal. 2018. Pengaruh ekstrak kunyit (Curcuma domestica) konsentrasi $75 \%$ terhadap motilitas dan mortilitas cacing Ascaridia galli secara in vitro. J. Ilmiah Mahasiswa Veteriner. 2 (1): 86-93.

Hayakawa HY, Minanyia K Ito, Y Yamamoto, and T Fukuda. 2011. "Difference of curcumin content in Curcuma longa L., (Zingiberaceae) caused by Hybridization with other Curcuma species," Journal American of Plant Sciences. 2 (2). 111119.

Kearl LC. 1982. Nutrient Requirement of Ruminant in Developing Countries. International Fedstuffs Institute, Utah Agriculture Experiment Stations, Utah State University, Logan Utah.

Kusbiantoro D dan Y Purwaningrum 2018. Pemanfaatan kandungan metabolit 
sekunder pada tanaman kunyit dalam mendukung peningkatan pendapatan masyarakat. J. Kultivasi. 17 (1): 543-549 .

McAnulty R and T Cook. 2019. Wormwise: National Worm Management Strategy. Wormwise, Wellington.

Mulyadi T. 2018. Prevalensi Cacing Saluran Pencernaan pada Kambing Peranakan Etawa (PE) di Kelompok Tani Kecamatan Gedong Tataan Kabupaten Pesawaran Lampung. Fakultas Pertanian, Universitas Lampung, Bandar Lampung. (Skripsi).

Nurtjahyani SD dan DS Agustin. 2014. Prevalensi infeksi telur cacing nematode pada feses sapi potong (Boss $p$ ) dengan metode whitlock. Prosiding Seminar Nasional XI Biologi, Sains, Lingkungan dan Pembelajarannya. Surakarta, 7 Juni 2014. Fakultas Keguruan dan Ilmu Pendidikan Universitas Sebelas Maret, Surakarta. 539-543.

Oktofani LA dan JF Suwandi. 2019. Potensi tanaman pepaya (Carica pepaya) sebagai antihelmintil. J. Majority. 8 (1): 246-250.

Pangestika D, E Mirani dan ID Mashoedi. 2012. Pengaruh pemberian mumnyit (Curcuma domestica Val.) terhadap aktivitas fagositosis makrofag pada mencit BALB/C yang diinokulasi bakteri Listeria monocytogenes. J. Sains Medika. 4 (1): 63 70.

Prasetiadi RD, Heriyadi dan Y Yurmiati. 2017. Performa domba lokal jantan yang diberikan tambahan tepung kunyit (Curcuma Domestica Val.). J. Ilmiah Ternak.17(1): $52-58$.

Primawati SN, R Sucilestari dan L Zainiati. 2014. Pengaruh kurkumin kunyit putih (Curcuma zedoaria) terhadap keberadaan koloni bakteri pada limpa mencit yang diinfeksi Salmonella typhimurium. J. Ilmiah Biologi Bioscientist. 2 (1): 84-87.

Pujaningsih RI, BIM Tampoebolon, Widiyanto dan DW Harjanti. 2018. Evaluation of the effectiveness of the use of pepaya fruit latex in making herbal medicated multinutrition block as a local goat feed supplement. J. Animal Production. 20 (1): 39-44.

Qurniawan A. 2016. Kualitas daging dan performa ayam broiler di kendang terbuka pada ketinggian tempat pemeliharaan yang berbeda di Kabupaten Takalar Sulawesi Selatan. Tesis. Program Pascasarjana, Institut Pertanian Bogor. Bogor.

Rozi F, J Handoko dan R Febriyanti. 2015. Infestasi cacing hati (Fasciola sp.) dan cacing lambung (Paramphistomum sp.) pada sapi Bali dewasa do Kecamatan Tenayan raya Kota Pekanbaru. J. Sain Veteriner. 33 (1): 8-15.

Sari LORK. 2006. Pemanfaatan Obat Ttadisional dengan Pertimbangan Manfaat dan Keamanannya. Majalah Ilmu Kefarmasian, Vol. III, No.1, pp. 01 - 07. doi:10.7454/psr.v3i1.3394.

Singh S, AK. Pathak, M. Khan and R.K. Sharma. 2015. Multi-nutrient blocks with and without tanniferous leaf meal mixture: formulation and preparation under subtropical environment of jammu. J. Animal Research. 5 (1): 7-14.

Suharyono. 2014. Pengembangan suplemen pakan urea molases multi-nutrien blok (UMMB) menggunakan sumber protein tepung kedelai dan gliricidia sepium (Gs) untuk ternak ruminansia. J. Ilmiah aplikasi isotop dan radiasi. 10 (1) : 11-21.

WHO. 2003. Traditional medicine, http://www.who.int/mediacentre/factsheet s/fs134/en/, diakses Juni 2020.

Widiarso BP dan Wida WM. 2019. Respon Peternak terhadap Pencegahan dan Pengobatan Penyakit Cacing Gastrointestinal pada Kambing di Desa Klopo Kecamatan Tegalrejo Kabupaten Magelang. Jurnal Ilmu Peternakan dan Veteriner Tropis. 9 (2) : 76-82. DOI: https://doi.org/10.30862/jipvet.v9i2.68

Wulandari E. 2019. Uji Mikrobiologis Salmonella, Water Activity dan Total Bakteri Multi nutrien Blok Kombinasi Cangkang Kerang dan Cangkang Telur sebagai Sumber Mineral. Fakultas Peternakan dan Pertanian Universitas Diponegoro, Semarang. (Skripsi).

Zingare S, K Pajai, S Waghmare, MFMF Siddiqu, S Kuralkar, S Hajare and V Wankhade. 2018. Anthelmintic evaluation of Carica pepaya against gastrointestinal helminths of goats. J. Pharmacognosy and Phytochemistry. 7 (6): 1746-1748. 